\title{
Incidence of Dry Root Rot of Pigeonpea in North Eastern Karnataka, India
}

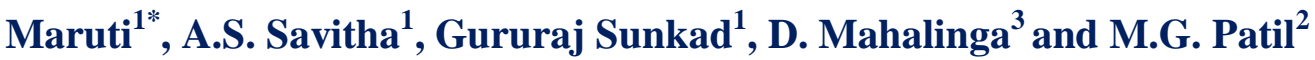 \\ ${ }^{1}$ Department of Plant Pathology, ${ }^{2}$ Department of Horticulture, College of Agriculture, UAS, \\ Raichur-584104, Karnataka, India \\ ${ }^{3}$ Main Agricultural Research Station Kalaburgi-585101, Karnataka, India \\ *Corresponding author
}

\section{A B S T R A C T}

\begin{abstract}
Keywords
Dry root rot,

Rhizoctonia

bataticola, Disease

incidence, BSMR-736.

Article Info

Accepted:

10 September 2017

Available Online:

10 November 2017

Pigeonpea (Cajanus cajan (L.) Millsp.) is one of the major pulse crop of tropics and sub tropics, cultivated by small and marginal farmers under rainfed condition. It is known to be affected by many fungal diseases among them dry root rot caused by Rhizoctonia bataticola (Taub.) Butler, is a major soil borne disease causing considerable yield loss in most of the pigeonpea growing regions of India more so in the North-Eastern Karnataka. Keeping this in view, an intensive roving survey was carried during the month of October-November 2015 in the farmer's field at Raichur, Kalaburgi, Yadgir and Bidar districts to know the incidence of the disease. The mean maximum dry root rot incidence was noticed in Kalaburgi district $(24.72 \%)$ followed by Raichur $(17.78 \%)$ and least in Yadgir $(9.44 \%)$.
\end{abstract}

\section{Introduction}

Pigeonpea (Cajanus cajan (L.) Millsp.) is one of the major pulse crop of tropics and sub tropics. It is cultivated by small and marginal farmers under rainfed condition because of its ability to tolerate against drought and residual moisture. The crop is able to fix atmospheric nitrogen there by increases the soil fertility (Reddy et al., 1990; Smita et al., 2015). In India, it is used as an important dietary protein to a large number of the people especially the vegetarians and the poor. Pigeonpea contributes 5 per cent of world legume production (Hillocks et al., 2000) and more than 70 per cent is being produced in India. Pigeonpea is cultivated in India an area about $4.01 \mathrm{~m}$ ha with a production of $2.65 \mathrm{~m}$ t. (Directorate of Economics and Statistics,
2011-12). There are several constraints of pigeonpea production because of its susceptibility to diseases, pests and other physiological stress.

Pigeonpea affected by more than 200 pathogens among them 83 are fungi (Nene et al., 1989). Recently, Rhizoctonia bataticola (Taub.) Butler (Macrophomina phaseolina (Tassi) Goid) emerged as soil borne pathogen of different agricultural crops including pigeonpea (Kaur et al., 2012). R. bataticola is having more than 500 host plants including cultivated and wild plant species belonging to 100 families around the world (Mihail and Taylor, 1995 and Pande et al., 2004). The pathogen is very severe especially when an 
off-season summer crop is taken particularly in black soil (Nene et al., 1979). Under favourable condition, disease will infect quickly and cause huge economic losses ranging from 10-100 per cent (Smita, et al., 2015). Recently under field condition dry root rot was noticed in pigeonpea as major proportion in the farmer holdings which has significant effect on plant diversity and yield with current scenario of increasing temperature due to global warming this disease gaining importance in field. Keeping in this view the present study was undertaken to survey for the prevalence of dry root rot of pigeonpea during October - November, 2015 at different places of North Eastern Karnataka.

\section{Materials and Methods}

A roving survey for prevalence of dry root rot of pigeonpea was carried out during October November, 2015 at different places of North Eastern Karnataka to know the incidence of dry root rot of pigeonpea in the farmer's field at Raichur, Kalaburgi, Yadgir and Bidar districts. In each district three major pigeonpea growing taluks were selected with three villages and in each village three fields were surveyed and then their incidence was assessed by counting the number of plants showing symptoms in three representative 80100 plants randomly chosen in each field. Then the per cent disease incidence was calculated by using the formula given below.

Per cent Disease Incidence $(\mathrm{PDI})=$

Number of plants infected x 100

Total number of plants examined

\section{Collection and isolation of the pathogenic isolate}

The field survey was carried out during October- November, 2015, a large number of infected pigeonpea roots were collected from different place viz., Raichur, Kalaburgi, Bidar and Yadgir districts. These samples were subjected to standard tissue isolation. The pigeonpea roots showing typical bark feeling and disintegrated roots were cut into small bits measuring about $2 \mathrm{~mm}$ and surface sterilized in $\left(\mathrm{HgCl}_{2}\right)(0.1 \%)$ for one minute and washed repeatedly twice in sterile distilled water to remove the traces of $\mathrm{HgCl}_{2}$ before transferring them to sterile potato dextrose agar (PDA) plates under aseptic conditions. The plates were incubated at temperature of $28 \pm 2{ }^{\circ} \mathrm{C}$ and observed for fungal growth. Thus the pure culture of the fungus was obtained by hyphal tip isolation method.

The pathogenicity test was conducted on moderately susceptible cultivar BSMR-736 in sick pots. Surface sterilized ( $0.1 \%$ formalin) earthen pots (15 cm diameter) were filled (2 $\mathrm{kg} / \mathrm{pot}$ ) with autoclaved soil (3 consecutive sterilization for 3 days at $1.1 \mathrm{~kg} / \mathrm{cm}^{2}$ for $1 \mathrm{~h}$ ) and inoculated for five days prior to sowing with the 20 days old giant culture $(20 \mathrm{~g} / \mathrm{kg}$ soil). And surface sterilized seeds of BSMR736 were sown in each pot in three replications and observed regularly for symptom development.

\section{Results and Discussion}

\section{Symptoms of dry root rot in the field}

The severe symptoms of dry root rot of pigeonpea was observed during crop at flowering and maturity stage even though the infection occurs early stage of the crop and some time disease seen in the seedling stage also. Root rot infected plants showing drooping and drying of leaves (Plate 1), the root system of such infected plant showed dark and extensive rotting, destroyed lateral roots, roots become brittle with shredding of the bark and easily peeled off (Plate 2). The affected plants could easily pull out from the 
soil (Smita et al., 2015) and showed discoloration of roots by the presence of black colored microsclerotia on roots.

\section{Isolation and pathogenicity}

$R$. bataticola isolated from infected plants collected from different places of North Eastern Karnataka varied in cultural and morphological characters such as mycelium and sclerotial formation were studied from nine days old culture. The mycelium was pale white in color in the initial stages of the growth, later turned to dark brown to black as and when sclerotia formation started (Plate 3).

The constriction of the hyphae at the point of branching was observed, aerial mycelium aggregated to form numerous dark brown to black colored sclerotia noticed on the culture. Mycelial branching was right and acute angled and moniloid cells (specialized hyphae composed of compact cells) were also observed (Ou et al., 1985) (Plate 3-6). The monilioid cells fuse together to produce hard structures called sclerotia. These are varied in shape, size and growth pattern of scattered to cluster. Based on the morphology and cultural characters of the mycelium and sclerotia, the fungus was identified as $R$. bataticola.

\section{Prevalence and distribution of dry root rot}

The crop is cultivated both in red sandy loam and black soils of different places of North Eastern Karnataka, mainly intercropped with cereals, vegetables and other pulses such as cowpea, greengram, and blackgram etc., and it is also grown as solo crop in some areas especially in major pigeonpea growing areas of Karnataka like Kalaburgi, Bidar and Raichur. For that a roving survey was conducted during October- November 2015 to assess the status of dry root rot incidence under field condition. The overall incidence of dry root rot ranged from 5.00 to 37.50 per cent across the districts and taluks (Table 1).

The mean maximum dry root rot incidence was observed in Kalaburgi district $(24.72 \%)$ followed by Raichur (17.79 \%) and the least was in Yadgir (9.44\%). In Kalaburgi, the highest disease incidence $(37.50 \%)$ was noticed in Sannur village of Chittapur and least was in Evani (15.00 \%).

However, in Raichur district, the maximum incidence was noticed in Shaktinagar (25.00 $\%)$ and the least was in Kallur (12.50\%) village of Manvi taluk. In Bidar district, the disease incidence is more in Chickpet (25\%) and KVK (22.50\%) of Bidar taluk and the least incidence was observed in Kudambal $(10.00 \%)$ of Humnabad taluk. The maximum incidence in Yadgir was in Gurumitkal of Yadgir taluk and Kodekal in Shorapur (15.00 $\%)$ and least was in Doranahalli village (5.00 $\%$ ) of Shahapur taluk. The overall incidence of dry root rot ranged from 5.00 to 37.50 per cent across the districts and taluks.

In recent years dry root rot is newly emerging disease in North Eastern Karnataka and more severe in Kalaburgi district $(24.72 \%)$ as compared to Raichur (17.79\%) and least incidence was recorded in Yadgir $(9.44 \%)$. The incidence of dry root rot was maximum $(37.50 \%)$ in Sannur village of Chittapur taluk and least was noticed in Doranahalli village $(5.00 \%)$ of Shahapur taluk (Fig. 1). The high incidence in Sannur village may be attributed to the monocropping of TS-3R variety in larger area, which might be responsible for existence of aggressive pathogen. The least incidence in Doranahalli village could be attributed to the cultivar usage of kattibeeja variety, which might have shown resistance against the disease. Such variations in disease incidence in different locations is usually attributed to environmental and/or cultivar variations. 
Plate.1 Infected plant showing yellowing, drying and falling of leaves (A-B)
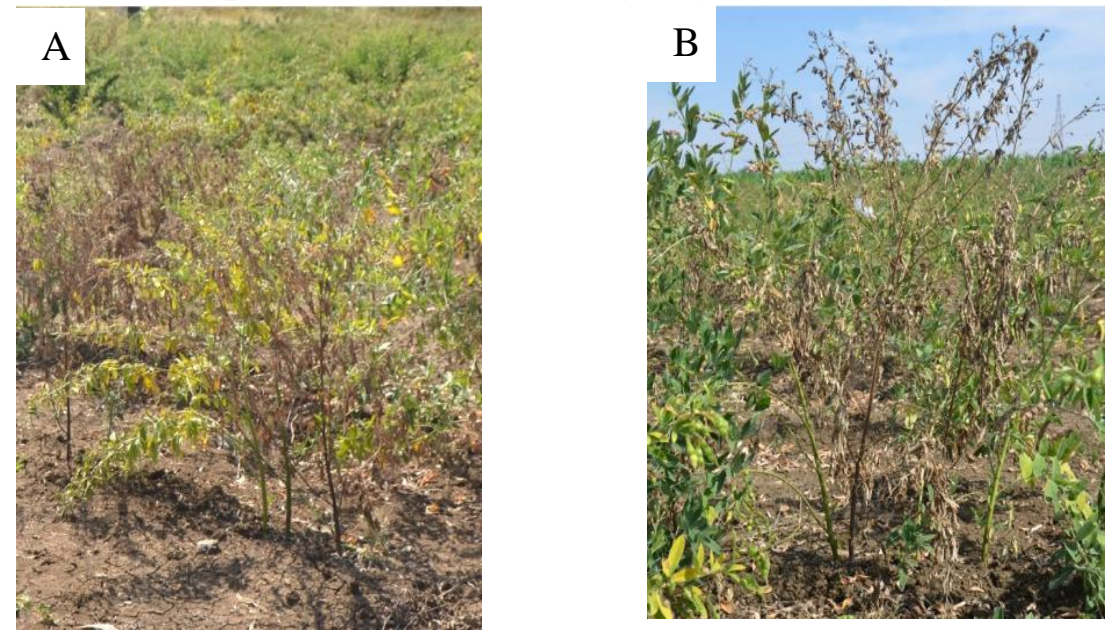

Plate.2 Infected pigeonpea plant showing disintegration and Bark shredding symptom of root system (C-D)
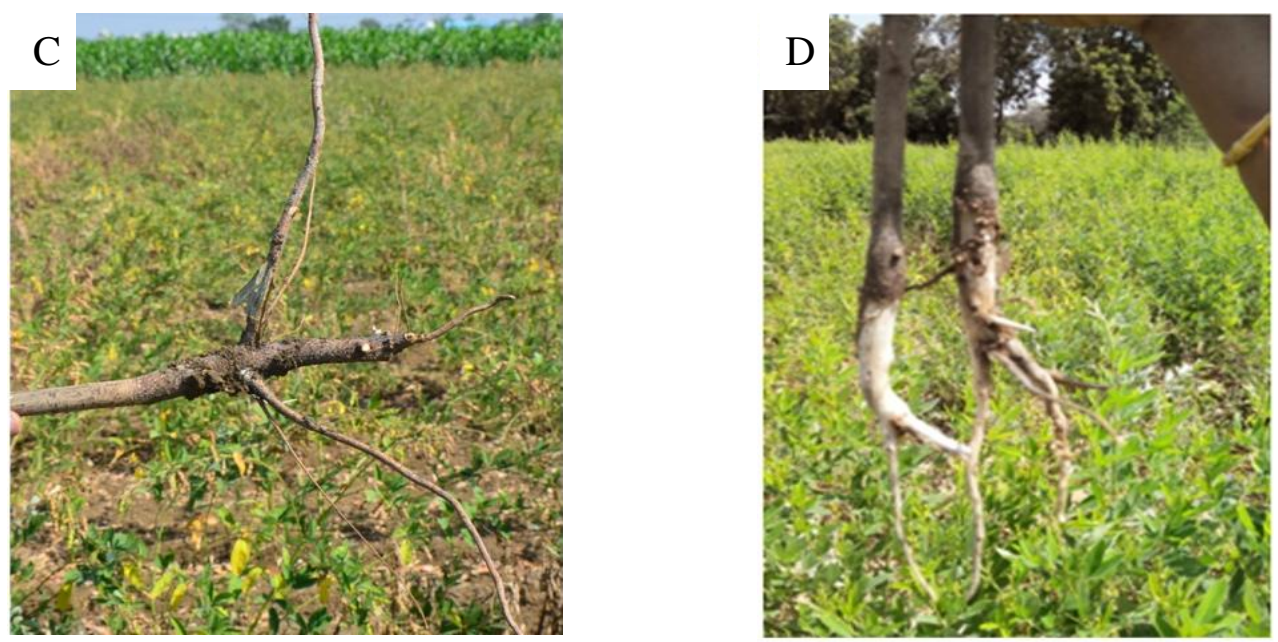

Plate.3 Pure culture of $R$. bataticola, Plate.4 Sclerotial bodies of $R$. bataticola, Plate.5 Right (R) and Acute (A) angle branching mycelium, Plate.6 Moniliod cells formation

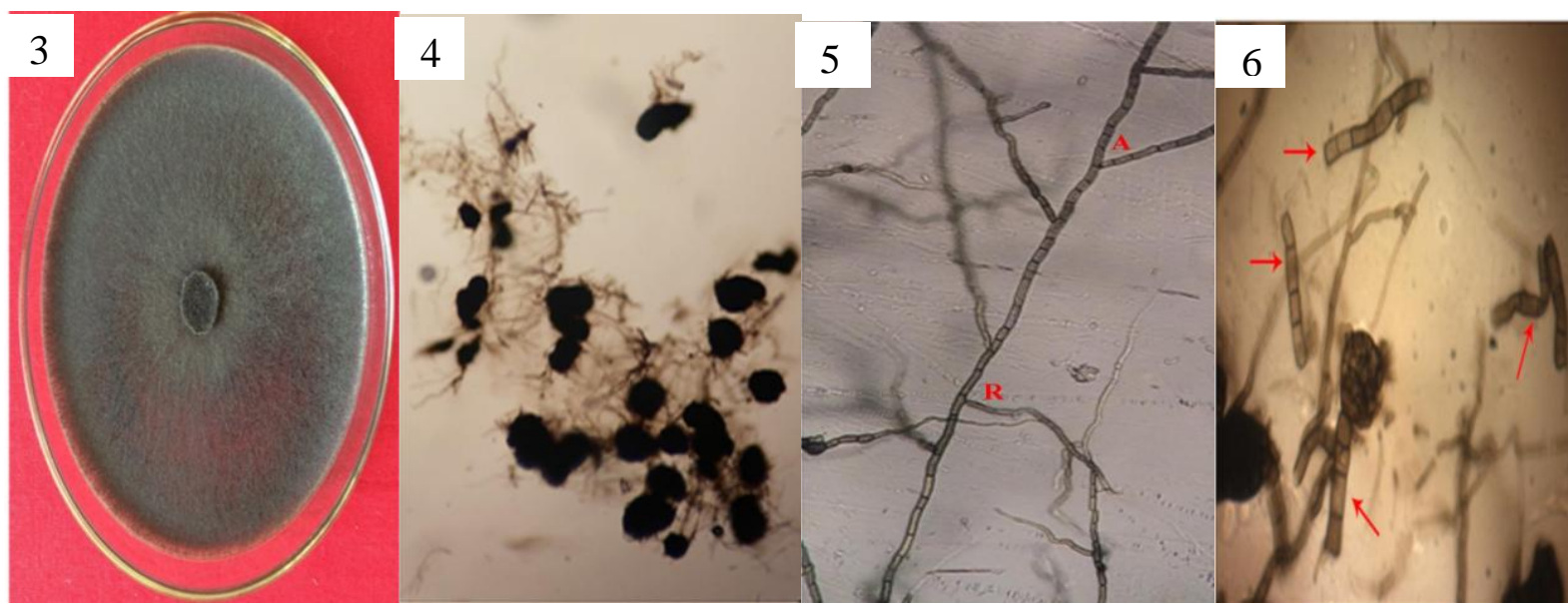


Table.1 Incidence of dry root rot of pigeonpea in the parts of North Eastern Karnataka during the month of October- November 2015

\begin{tabular}{|c|c|c|c|c|c|}
\hline $\begin{array}{l}\text { SI. } \\
\text { No. }\end{array}$ & District & Taluk & Village & Variety & $\begin{array}{c}\text { Disease } \\
\text { incidence }(\%)\end{array}$ \\
\hline \multirow{13}{*}{1.} & \multirow{12}{*}{ Raichur } & \multirow{3}{*}{ Raichur } & Huninalahuda & TS-3R & 17.50 \\
\hline & & & Shaktinagar & Gulyal Red & 25.00 \\
\hline & & & Yergera & Local & 15.00 \\
\hline & & \multicolumn{3}{|c|}{ Mean } & 19.17 \\
\hline & & \multirow{3}{*}{ Deodurga } & Gabbur & TS-3R & 22.50 \\
\hline & & & Masarkal & Local & 12.60 \\
\hline & & & Deodurga & Karitogari & 17.50 \\
\hline & & \multicolumn{3}{|c|}{ Mean } & 17.53 \\
\hline & & \multirow{3}{*}{ Manvi } & Kallur & TS-3R & 12.50 \\
\hline & & & Kurdi & TS-3R & 22.50 \\
\hline & & & Kavital & TS-3R & 15.00 \\
\hline & & \multicolumn{3}{|c|}{ Mean } & 16.67 \\
\hline & \multirow{13}{*}{ Kalaburgi } & & & & 17.79 \\
\hline \multirow{13}{*}{2.} & & \multirow{3}{*}{ Kalaburgi } & ARS, Kalaburgi & TS-3R & 32.50 \\
\hline & & & Marthur & TS-3R & 27.50 \\
\hline & & & Khanadal & Kattibeeja & 17.50 \\
\hline & & \multicolumn{3}{|c|}{ Mean } & 25.83 \\
\hline & & \multirow{3}{*}{ Chittapur } & Sannur & TS-3R & 37.50 \\
\hline & & & Gundakurti & Kattibeeja & 27.50 \\
\hline & & & Evani & Double mung & 15.00 \\
\hline & & \multirow{4}{*}{ Jewargi } & \multicolumn{2}{|l|}{ Mean } & 26.67 \\
\hline & & & Jewargi & Double mung & 17.50 \\
\hline & & & Tigralli & TS-3R & 22.50 \\
\hline & & & Kellur & TS-3R & 25.00 \\
\hline & & \multicolumn{3}{|c|}{ Mean } & 21.67 \\
\hline & & & & & 24.72 \\
\hline \multirow{13}{*}{3.} & \multirow{12}{*}{ Bidar } & \multirow{3}{*}{ Humanabad } & Sann Hallikhed & Pinko & 20.00 \\
\hline & & & Chitaguppa & BSMR-736 & 11.00 \\
\hline & & & Kudmbal & TS-3R & 10.00 \\
\hline & & & Mean & & 13.67 \\
\hline & & & KVK, Bidar & BSMR-736 & 22.50 \\
\hline & & Bidar & Janawad & BSMR-736 & 20.00 \\
\hline & & & Chickpet & Maruti & 25.00 \\
\hline & & & Mean & & 22.50 \\
\hline & & & Muchalamb & TS-3R & 11.00 \\
\hline & & Basavakalyan & Manthal & TS-3R & 12.50 \\
\hline & & & Bettadkund & TS-3R & 15.00 \\
\hline & & & Mean & & 12.83 \\
\hline & & & & & 16.33 \\
\hline & & & Gurumitkal & Maruti & 15.00 \\
\hline & & Yadagir & Yargal & TS-3R & 10.00 \\
\hline & & & Ramsamudra & TS-3R & 7.50 \\
\hline & & & Mean & & 10.83 \\
\hline & & & Bheemarayanagudi & TS-3R & 7.50 \\
\hline & & Shahapur & Doranahalli & Kattibeeja & 5.00 \\
\hline 4. & Yadgir & & Alishnagar & Gulyal Red & 10.00 \\
\hline & & & Mean & & 7.50 \\
\hline & & & Hunasagi & TS-3R & 7.50 \\
\hline & & Shorapur & Kakkeri & Karitogari & 7.50 \\
\hline & & & Kodekal & TS-3R & 15.00 \\
\hline & & & Mean & & 10.00 \\
\hline & & & an & & 9.44 \\
\hline
\end{tabular}


Fig.1 Incidence of dry root rot of pigeonpea in different taluks of North Eastern Karnataka during kharif-2015

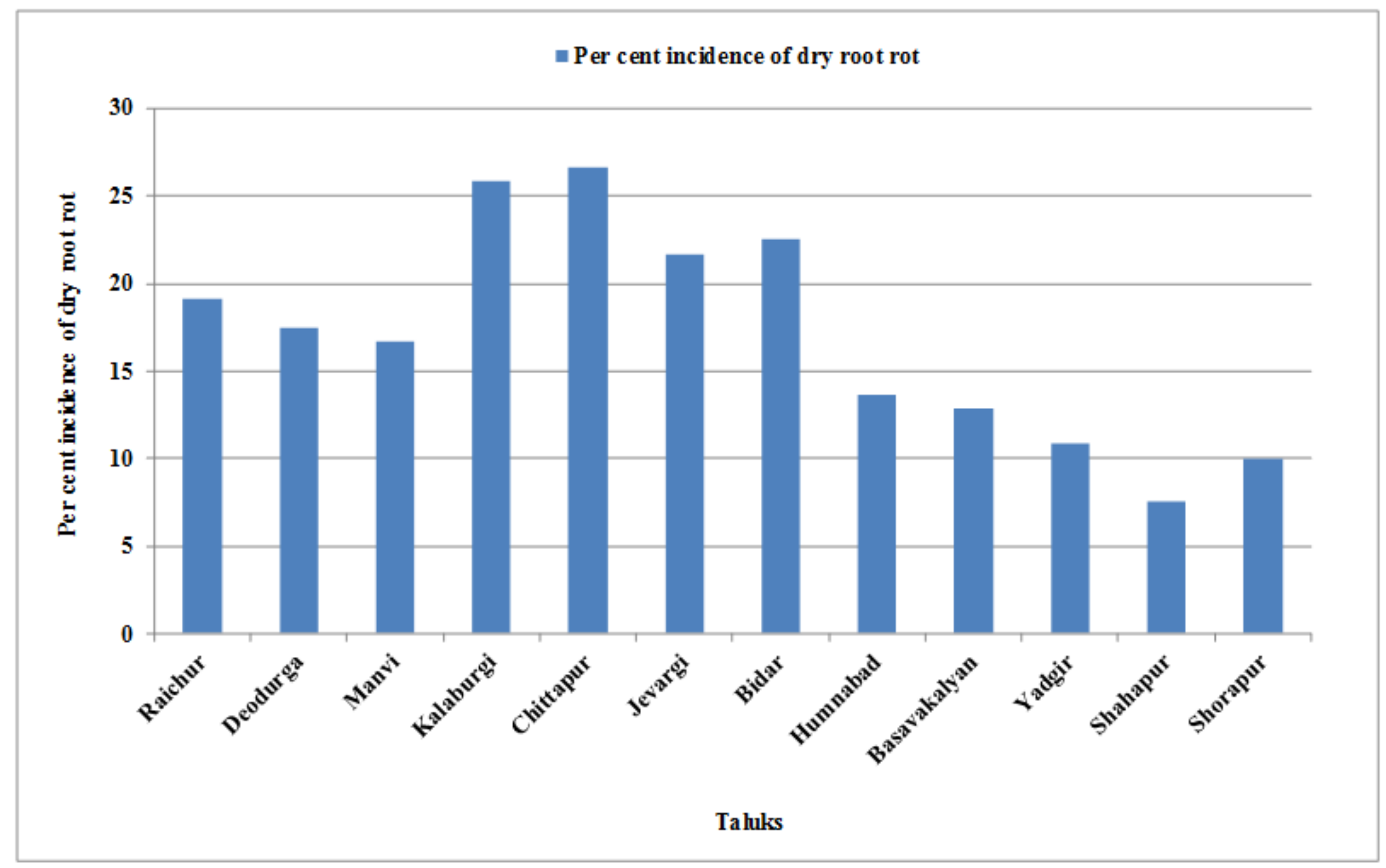


However, the variations may also be attributed to the presence of variability in pathogenic fungus and its sclerotial bodies (Pande et al., 2004) and even also due to variation in weather parameters which affected growth and development of disease. The average temperature of $27-35{ }^{\circ} \mathrm{C}$ and prolonged dry spell (Rainfall $20 \mathrm{~mm}$ ) from flowering to harvesting stage was observed in Kalaburgi during Nov-Feb 2015, which was resulted in enhanced disease. These observations corroborate the results of Bajpal et al., (1999), Yang and Navi, 2003, Vijay Mohan et al., (2005), Manjunath et al., (2011) and Smitha et al., (2015). Mono-cropping with closer spacing and also drought and high temperature increased the vulnerability of the crop and enhanced the aggressiveness of the pathogen. The present findings are also supported by Garrett et al., (2006) and Kaur et al., (2012).

Dry root rot is mainly enhanced by moisture stress and prolonged dry spell at maturity stage. This observations are agreement with the Tariq Hussain et al., (1997) and Manjunath et al., (2011) where they reported that chickpea plants to moisture stress conditions evidenced during rabi season, which ultimately led to more production of sclerotia of Rhizoctonia sp. on chickpea plants roots (Pande et al., 2004). Later, Wokocha (2000) stated that, the disease incidence of dry root rot of soybean was significantly low when the soil moisture was $60-70$ per cent but it was 5.0 per cent at $10-20$ per cent soil moisture. The pigeonpea is a rainfed crop depends on the rainfall for its growth and development, since 2011-12 there has been a prolonged dry spell during the maturity in North Eastern Karnataka which perhaps could be the reason for increased incidence (Nobel and Richardson,1968); Bajpal et al., (1999).

Present investigation provides severity of dry root rot pathogen, $R$. bataticola in different places of North Eastern Karnataka. The pathogen gaining more importance especially in the current scenario of increasing temperature due to global warming. Even though various control measures are taken so for, more focus on epidemiological aspects of the pathogen should be the need of the hour, which will help for the disease management under field condition.

\section{References}

Bajpal, G. C., Singh, D. P. and Tripathi, H. S. 1999. Reaction of pigeonpea cultivars to a sudden appearance of Macrophomina stem canker at Pantnagar, India. International Chickpea and Pigeonpea News Letter, 6: 41-42.

Garrett, K. A., Dendy, S. P., Frank, E. E., Rouse, M. N. and Travers, S. E. 2006. Climate change effects on plant disease: genomes to ecosystems. Ann. Rev. Phytopath., 44: 489-509.

Hillocks, R. J., Minja, E., Silim, S. N. and Subrahmanyam, P. 2000. Diseases and pests of pigeonpea in eastern Africa. Int. J. Pest Manage, 46: 7-18.

Kaur, S., Chauhan, V. B., Singh, J. P. and Singh, R. B. 2012. Status of Macrophomina stem canker disease of pigeonpea in eastern Uttar Pradesh. Journal of Food Legumes, 25(1): 76-78.

Manjunatha, S. V., Naik, M. K., Patil, M. B., Devikarani, G. S. and Sudha, S. 2011. Prevalence of dry root rot of chickpea in North-Eastern Karnataka. Karnataka J. Agric. Sci., 24 (3): 404-405.

Mihail, J. D. and S. J. Taylor. 1995. Interpreting variability among isolates of Macrophomina phaseolina in pathogenicity, pycnidium production and chlorate utilization. Can. J. Bot. 73: 1596-1603.

Nene, Y. L., J. Kannaiyan, M.V. Reddy, K.K. Zote, M. Mahmood, R.V. Hiremath, P. Shukla, S.R. Kotasthane, K. Sengupta, 
P.K. Jha, M.F. Haque, J.S. Grewal and Mahendrapal. 1989. "Multilocational testing of Pigeonpea for broad based resistance to Fusarium wilt resistance in India", Indian Phytopathology, 42, 449453.

Nene, Y. L., Kannaiyan, J., Haware, M. P. and Reddy, M. V. 1979. Proc. Consultants Group Discussion on the Resistance of Soil-Borne Diseases of Legumes, ICRISAT. pp. 3-39.

Noble, M. and Richardson, M. J. 1968. An annotated list of seed borne diseases. Phytopath, 8: 191.

Ou, S. H. 1985. Rice Diseases. CAB International, Leutralsales, Fanham Royals Slough, UK, p. 380.

Pande S., G. K. Kishore and J. N. Rao. 2004. "Evaluation of Chickpea Lines for Resistance to Dry Root Rot Caused by Rhizoctonia bataticola," ICPN, No. 11, p. 37.

Reddy, M. V., Nene, Y. L., Kannaiyan, J., Raju, T. N., Saka, V. N., Davor, A. T., Songa, W. P. and Omanga, P. 1990. Pigeonpea lines resistant to wilt in
Kenya and Malawi. International Pigeonpea Newsletter 16: 34

Smitha, K. P., Rajeswari, E., Alice, D. And Raguchander T. 2015. Assesment of Vascular Wilt and Dry Root Rot of Pigeonpea in Tamil Nadu, International J. of Tropical Agri., 33(3): 2145-2151.

Tariq Hussain, Abdul Ghaffar, Husain,T. and Ghaffar, A. 1997. Effect of soil moisture on the colonization of $R$. bataticola on roots of chickpea. Pakistan J. Bot., 27(1): 221-225.

Vijay Mohan, Prasad, S.M., Barnwal, M.K. and Kudada, N. 2005. Influence of weather conditions on dry root rot disease in chickpea. J. Mycol. Pl. Pathol., 35 (2): 380-384

Wokocha, R.C. 2000. Effect of different soil moisture regimes on the development of the charcoal rot disease of soybean by $M$. phaseolina. Global J. Pure and Applied Sci., 6(4): 599-602.

Yang, X. B. and Navi, S. 2003. Charcoal Rot - A dry weather disease. Integrated Crop Management, 22: 166-167.

\section{How to cite this article:}

Maruti, A.S. Savitha, Gururaj Sunkad, D. Mahalinga and Patil, M.G. 2017. Incidence of Dry Root Rot of Pigeonpea in North Eastern Karnataka. Int.J.Curr.Microbiol.App.Sci. 6(11): 10711078. doi: https://doi.org/10.20546/ijcmas.2017.611.126 